\title{
BIMBINGAN KONSELING DI MADRASAH
}

\section{Muhamad Irham}

PGSD STKIP ISLAM Bumiayu

Jl. Raya Pagojengan Km 3 Paguyangan Kab. Brebes 52276

Email: irham_galuh@yahoo.co.id

\begin{abstract}
ABSTRAK
Tulisan ini bermaksud menawarkan model-konsep bimbingan integratifkomprehesif di MI (Madrasah Ibtidaiyah) yang belum ada format bakunya. Masalah dianalisis berdasarkan teori pendidikan Islam dan BK (bimbingan konseling). Hasil kajian menunjukkan bahwa BK integratif-komprehensif di MI meliputi tiga komponen yaitu; 1) kepemimpinan/manajerial; 2) pembelajaran; dan 3) pengembangan diri. Layanan BK integratif-komprehensif di MI selalu melibatkan orang tua murid. Isu integrasi keilmuan dalam pendidikan Islam turut mendukung penyusunan model-konsep BK ini. Karakteristik model BK integratif-komprehensif di MI yaitu ada keterpaduan pada program, ketenagaan, perosedur, dan sistem layanan. Model ini pun bercirikan dapat mengembangkan aspek kepribadian, sosial, akademik/belajar, karir, dan akhlak siswa. Format RPP dikembangkan agar peserta didik sadar pentingnya bersyukur kepada Allah swt. Ilmu yang dimiliki, kesungguhan dalam mencari ilmu dan mengamalkannya, kemauan untuk berprestasi dan unggul dibidangnya, serta terinternalisasinya sikap sosial yang baik atas dasar pemahaman dirinya sebagai makhluk Allah, diharapkan dapat menciptakan lulusan MI yang unggul dan siap bersaing.
\end{abstract}

Kata Kunci : Bimbingan Konseling, MI, Integratif-Komprehensif.

\section{ABSTRACT}

This paper intends to offer a model - concept integrative - comprehensive guidance in MI that no format. The problem is analyzed based on the theory of Islamic education and the needs in MI. The results of the study showed that the concept of integrative - comprehensive in Counseling in MI education includes three main components, namely: 1) leadership/managerial; 2) learning, and 3) self-development. BK integrative-comprehensive services in MI involving parents. The issue of integration of knowledge in Islamic education contributed to the preparation of - concept model of integrative - comprehensive BK in MI. Characteristics of integrative - comprehensive model of BK in MI is no coherence in the programs, workforce, perosedur, and system services. This model was characterized to develop aspects of personality, social, academic/learning, career, and even decency students. Developed lesson plan format includes objectives so that learners are aware of the importance of gratitude to God Almighty. His knowledge, sincerity in seeking knowledge and practice it, willingness to perform and excel in their field, as well as internalized social attitudes on the basis of better knowledge and understanding of himself as God 's creatures, MI graduates are expected to create superior and ready to compete.

Keywords : Guidance Counseling, MI, Integrative-Comprehensive. 


\section{PENDAHULUAN}

Pendidikan nasional saat ini telah memasuki fase jenuh terhadap banyaknya permasalahan yang belum terpecahkan. Pendidikan terus menjadi "kambing hitam" yang akan selalu disalahkan dan digugat ketika muncul permasalahan sosial kemasyarakatan yang tidak kondusif, kondisi ekonomi bangsa yang memprihatinkan, bahkan krisis multidimensi yang mengarah pada dekadensi moral, kepribadian, dan prestasi. Dunia pendidikan secara umum seolah tidak berdaya membebaskan diri dari permasalahan yang membelenggunya. Dampaknya, tidak sedikit orang yang mencerca dan menyalahkan bahkan mengutuk kegagalan dunia pendidikan dalam memperbaiki kondisi bangsa (Tafsir, 2010: 41).

Pendidikan Indonesia selama ini dianggap telah gagal dalam melakukan transfer pengetahuan, pengalaman, kecakapan, dan keterampilan. Padahal hanya melalui kegiatan-kegiatan tersebut, pendidikan berupaya membekali generasi muda agar dapat memenuhi fungsi-fungsi kehidupannya baik dalam aspek jasmani maupun rohani, untuk lebih baik di masa mendatang (Nawawi, dalam Jurnal Insania, Vol. 16 No. 2, Mei-Agustus 2011: 122). Tidak hanya cerdas secara kognitif saja akan tetapi seimbang dan komprehensif melingkupi tiga aspek utama pendidikan yaitu kognitif, afektif, dan psikomotorik sebagaimana dijabarkan Spear, Penrod, dan Baker (Suwarna, dalam Cakrawala Pendidikan, Februari 2007, Th. XXVI, No. 1 33). Afektif mencakup perasaan dan emosi, ranah kognitif mencakup pengetahuan, fakta, kepercayaan, dan pendapat, serta ranah tindakan atau psikomotorik berupa kemampuan fisik untuk merespons suatu objek. Kondisi tersebut menunjukkan bahwa peserta didik memang tidak cukup hanya memiliki sisi kognitif, akan tetapi butuh aspek afektif dan psikomotorik yang menjadi penyeimbang dan penyempurna pangetahuan yang dimiliki. Ini menunjukkan bahwa prinsip keseimbangan dalam pendidikan sangat penting diperhatikan.

Ketidakutuhan dan ketidakseimbangan aspek-aspek yang dikembangkan memunculkan permasalahan-permasalahan baru. Peserta didik yang cerdas tanpa afektif akan cenderung menjadikan peserta didik tidak memiliki etiket, tidak memiliki sopan santun, dan tidak mampu bergaul dengan lingkungan. Kecerdasan tanpa keterampilan akan membuat peserta didik cenderung banyak bicara, dan kenakalan remaja tidak terkontrol dan semakin brutal. Kondisi tersebut menambah kekhawatiran orang tua terhadap pendidikan anaknya. Tidak sedikit orang tua yang mengkhawatirkan, apakah anaknya masuk dalam lingkungan yang baik, atau sebaliknya justru masuk ke dalam kelompok yang tidak baik. Sehingga masyarakat luas (para orang tua) berpikir keras saat akan menyekolahkan anaknya, mereka akan bertanya, sekolah manakah yang dapat menjamin anak saya tidak akan nakal? Jawabannya, coba masukkan saja ke sekolah yang berbasis Islam atau berbasis agama (Tafsir, 2010: 188). Jawaban tersebut memberikan indikasi bahwa pendidikan Islam merupakan solusi alternatif atas permasalahan moral pendidikan, dan menjadi harapan baru dunia pendidikan 
nasional. Artinya, pendidikan Islam mulai berpotensi menunjukkan eksistensinya kembali. Akan tetapi, fakta di lapangan menunjukkan bahwa mutu madrasah masih menjadi isu dan persoalan utama yang senantiasa dibicarakan dalam setiap forum pendidikan Islam. Madrasah masih dianggap belum berkualitas dalam menghasilkan lulusannya yang siap bersaing dengan sekolah umum. Para orang tua masih bertanya-tanya, "mau jadi apa setelah lulus dari Madrasah?" Artinya, madrasah belum mampu menjamin kualitas kecerdasan, sikap, dan keterampilan muridnya, dan belum dianggap sebagai sekolah yang mampu mewujudkan kepribadian siswa secara utuh.

Dari sudut pandang manajemen, ini terjadi karena tidak terpenuhinya tiga komponen utama pendidikan secara utuh yaitu; manajemen yang sehat, pembelajaran yang mencerdaskan dan bimbingan yang memandirikan sesuai PP No.22/2006. Ketiga komponen tersebut hendaknya saling berintegrasi dan terpadu untuk mengembangkan peserta didik secara lebih komprehensif (Azra, 2006: 71). Kondisi ini merupakan dampak dari masih adanya dikotomi ilmu pengetahuan.

Mengacu pada kondisi di atas, aspek ketiga dalam pendidikan yaitu kegiatan pengembangan diri dapat dilakukan melalui kegiatan bimbingan dan konseling. Kepribadian menjadi faktor utama sekaligus indikator berkualitas tidaknya sebuah proses pendidikan, di mana semua itu hanya akan terwujud dengan adanya kegiatan bimbingan (Slameto, 2010: 73). Keberhasilan program bimbingan hanya akan tercapai ketika adanya kesinambungan pada setiap jenjang dan jenis pendidikan, serta adanya model dan sistem organisasi yang jelas. Tulisan ini bermaksud menawarkan model-konsep bimbingan integratifkomrehesif di madrasah ibtidaiyah yang belum ada format bakunya. Data dikumpulkan melalui kepustakaan selanjutnya dianalisis berdasarkan teori pendidikan Islam dan kebutuhan di Madrasah Ibtidaiyah.

\section{PEMBAHASAN}

Bimbingan menurut PP No. 29/1990 merupakan bantuan yang diberikan kepada peserta didik dalam rangka membantu peserta didik menemukan jati diri pribadinya, mengenal lingkungan, dan merencanakan masa depan (Ludin, 2010: 3). Untuk itu, menurut Moh. Surya, proses bimbingan harus diberikan secara sistematis agar peserta didik benar-benar mampu mencapai kemandirian dalam pemahaman, penerimaan, pengarahan, dan perwujudan diri sebagai wujud pencapaian perkembangan yang optimal, dan mengubah perilaku anak yang berdampak negatif (Sukardi \& Kusmawati, 2008: 2; Geldard \& Geldard, 2001: 3). Untuk mencapai tujuan tersebut dibutuhkan model bimbingan yang jelas mulai dari konsep sampai operasionalisasinya di lapangan, tidak terkecuali di madrasah.

Keberadaan bimbingan di madrasah tidak lain adalah untuk membentuk peserta didik yang utuh dan seimbang secara aspek kepribadian, sosialkemasyarakatan, keberagamaan, dan kesusilaan untuk menjadi manusia yang 
seutuhnya, serta menumbuhkan dan mengembangkan aspek-aspek kognitif, afektif, dan psikomotorik secara seimbang. Ketika semua itu terlaksana, pada akhirnya akan membantu peserta didik mencapai perkembangan dirinya yang optimal dalam bentuk aspek kepribadian, sikap dan perilaku sosial, prestasi belajar, serta tercapainya cita-cita karir yang memuaskan (Yusuf \& Nurihsan, 2011: 14-16). Tujuan-tujuan tersebut tidak serta merta akan tercapai hanya dengan adanya program bimbingan di madrasah. Semua itu hanya akan terjadi jika ada kerja sama dan saling dukung dari semua komponen, antara guru mata pelajaran dengan guru pembimbing, pihak sekolah dengan orang tua, dan sekolah dengan masyarakat. Terlebih lagi untuk tingkat ibtidaiyah yang tidak memiliki guru pembimbing secara khusus. Oleh sebab itu, untuk menjamin layanan bimbingan sesuai dengan prosedur dan tujuannya, maka perlu memperhatikan prinsip-prinsip pelaksanaan bimbingan yaitu jelasnya sasaran layanan, permasalahan yang dihadapi, program layanan, dan pelaksanaan layanan (Prayitno \& Amti, 2009: 219-222).

Prinsip sasaran layanan bimbingan menghendaki kegiatan layanan mencakup seluruh individu yang ada di lingkungan sekolah tanpa terkecuali. Prinsip masalah yang ditangani lebih banyak terkait dengan fisik dan psikologis (penyesuaian dan prestasi belajar) serta lingkungan yang menghambat perkembangan peserta didik. Sedangkan prinsip program layanan bimbingan dan konseling dilaksanakan sejalan dan terpadu dengan progam pendidikan, fleksibel, berkesinambungan, dan komprehesif.

Terkait dengan prinsip layanan, Prayitno \& Erman Amti memberikan catatan khusus, yaitu harus memperhatikan unsur keterpaduan yang komprehensif dengan program pendidikan. Hal ini dikarenakan bimbingan dan konseling di sekolah merupakan bagian yang integral dengan proses pendidikan itu sendiri, atau dengan kata lain ada keterkaitan, kesinambungan, dan keterpaduan antara program pendidikan dan bimbingan konseling agar proses pendidikan dapat berjalan dengan baik dan dapat memenuhi keperluan peserta didik secara optimal (Luddin, 2010: 30).

Unsur keterkaitan, kesinambungan, dan keterpaduan atau model integrataif-komprehensif layanan bimbingan dan konseling akan sangat terlihat pada jenjang madrasah ibtidaiyyah. Hal ini tidak terlepas dari kondisi peserta didik di MI dengan berbagai ciri khas dan juga kekhasan KBM-nya. Oleh sebab itu, layanan bimbingan dan konseling di MI akan sangat berbeda dan harus berbeda dengan di tsanawiyyah dan aliyah. Hal ini dikarenakan salah satu penekanan dalam bimbingan adalah pada pemahaman karakteristik peserta didik secara utuh. Ketika guru pembimbing memiliki pemahaman yang lebih baik tentang peserta didiknya, maka keberhasilan program-program bimbingan memiliki peluang yang jauh lebih besar. Oleh sebab itu, guru MI yang sekaligus guru mapel dan juga wali kelas dituntut memainkan peran bimbingan dan konseling. Dengan kata lain, layanan bimbingan dan konseling di MI dilaksanakan secara terpadu dan integrative-komprehensif. Hal ini didasari ada 
beberapa karaktersitik pembelajaran di SD yang sama persis dengan kondisi di MI, yaitu: 1) lebih menekankan pada fungsi dan peran guru kelas secara lebih massif. Hal ini dikarenakan peserta didik belajar seharian selama setahun akademik bersama guru wali kelas, dan jarang sekali mendapat pelajaran dari guru mata pelajaran yang berbeda. Hal ini berdampak pada guru dan siswa saling mengetahui satu sama lain dengan lebih baik; 2) KBM lebih menekankan pada aktivitas fisik; 3) tingkat keterlibatan orang tua masih sangat besar; 4) siswa SD sebagai sebuah kelompok yang relatif stabil dan permasalahan yang muncul tidak sekompleks di sekolah menengah, mayoritas lebih banyak pada masalah akademik (Gibson \& Mitchel, 2011:119).

\section{Paradigma Bimbingan di Madrasah}

Model bimbingan yang mulai dikembangkan dan dilaksanakan dewasa ini adalah model perkembangan yang dikembangkan oleh Wilson Little dan Chapman. Menurut Mathewson, pendekatan ini didasari oleh konsep bahwa setiap peserta didik memiliki kebutuhan untuk memahami dan menyesuaikan diri dengan lingkungan, memiliki wawasan serta berorientasi pada baik kondisi saat ini maupun yang akan datang, serta kebutuhan untuk mengembangkan potensi pribadi. Oleh sebab itu, layanan bimbingan dan konseling perlu dilakukan dan diberikan kepada semua peserta didik dalam berbagai aspeknya baik pekerjaan, pendidikan, kepribadian, maupun sosialnya. Mereka menegaskan bahwa landasan dan prinsip bimbingan konseling yang penting diperhatikan adalah aspek perkembangan peserta didik dengan berbagai kompleksitasnya. Bimbingan dan konseling hendaknya sangat memperhatikan proses pelaksanaan yang bersifat komprehensif, agar tujuan pelaksanaanya, yaitu perkembangan optimal peserta didik lebih bermakna bagi diri sendiri dan lingkungannya, dapat tercapai. Chris D. Kehas yang mengatakan bahwa perkembangan peserta didik merupakan fokus dari bimbingan dan konseling pendidikan (Yusuf \& Nurihsan, 2011: 53$55)$.

Robert Myrick juga meyakini bahwa pendekatan perkembangan merupakan pendekatan yang lebih mutakhir. Kelebihan pendekatan ini dibandingkan dengan yang lain (pendekatan klinis, remedial, dan preventif), adalah memberikan porsi perhatian yang lebih besar dan lebih serius terhadap tahap-tahap perkembangan peserta didik, kebutuhan, dan minat. Poin yang paling penting adalah membantu peserta didik mempelajari keterampilan hidup untuk mencapai keberhasilan baik di sekolah maupun di masyarakat (Kartadinata, 1999: 196). Kelebihan lain dari pendekatan perkembangan adalah memiliki kegiatan yang lebih kompleks dan komprehensif dengan visi edukatif, pengembangan, dan menyeluruh (outreach). Edukatif artinya menekankan pada pencegahan dan pengembangan. Pengembangan artinya tujuan yang ingin dicapai adalah perkembangan peserta didik secara optimal sesuai dengan tugastugas perkembangan melalui aktivitas dan rekayasa lingkungan. Outrech artinya 
layanan bimbingan dan konseling diberikan kepada seluruh peserta didik baik yang bermasalah ataupun tidak (Yusuf \& Nurihsan, 2011: 82).

Mengacu pada konsep yang ada, maka model perkembangan memfokuskan setiap kegiatannya pada seluruh peserta didik dalam membantu seluruh aspek pertumbuhan dan perkembangannya. Program bimbingan tidak semata-mata membahas anak krisis atau bermasalah, mencegah munculnya masalah, tetapi juga membahas problematika peserta didik lainnya seperti mendiskusikan peningkatan prestasi belajar, hubungan saling bantu antara sekolah dengan rumah, peningkatan keterampilan, bakat, minat dan aspek-aspek perkembangan lain yang menjadi kebuhan peserta didik. Dalam pendekatan ini, petugas yang memberikan layanan memiliki pengetahuan yang banyak tentang siswanya serta memiliki intensitas interaksi yang lebih banyak (Tidjan, dkk., 2000: 31).

Menurut Kehas, pendidikan dan bimbingan konseling merupakan dua bidang yang saling berhubungan, komplementer, dan kolaboratif. Bimbingan konseling dan pendidikan saling mendukung, pendidikan butuh bimbingan konseling dan bimbingan konseling tidak dapat lepas dari pendidikan. Oleh sebab itu, model bimbingan dan konseling perkembangan merupakan model yang paling ideal untuk dilaksanakan di sekolah dasar (MI atau SD) (Yusuf \& Nurihsan, 2011: 57). Dalam sistem pendidikan di MI, layanan bimbingan dan konseling harus menjadi tugas terpadu bagi guru kelas. Dalam pelaksanaannya guru perlu memperhatikan banyak aspek seperti program, ketenagaan, prosedur, dan dukungan sistem. Harapannya adalah maksimalnya pengembangan diri siswa dengan wilayah garapan pribadi, sosial, belajar, dan karir.

\section{Bidang Bimbingan Pribadi}

Layanan ini membantu peserta didik mengenal, menemukan, dan mengembangkan pribadi yang beriman dan bertaqwa kepada Tuhan YME, mandiri, serta sehat secara jasmani dan rohani (Marsudi, 2003: 85). Kepribadian yang dimiliki seseorang akan berpengaruh terhadap akhlak, moral, budi pekerti, etika, dan estetika ketika berinteraksi dan berkomunikasi dengan lingkungannya (Sjarkawi, 2011: 33). Oleh sebab itu, orientasi bimbingan dan konseling pribadi tidak lain adalah mengembangkan nilai, sikap, dan perilaku yang memancarkan akhlak mulia atau budi pekerti luhur sebagai modal hidup bermasyarakat.

Berkembangnya kepribadian dan bermasalahnya kepribadian peserta didik tidak lepas dari beberapa hal, yaitu: latar belakang (background) yang mewarnai karakter dan kepribadian peserta didik, pergaulan, lingkungan sekitar, dan pengasuhan sebagai bagian dari proses pendampingan peserta didik menuju kedewasaan. Untuk itu, peserta didik perlu dibantu dalam mengembangkan nilainilai kepedulian dan empati, kerjasama, berani, komitmen dan keteguhan hati, kejujuran dan integritas, mandiri dan percaya diri, serta tanggung jawab di sekolah dengan melibatkan lingkungan yang ada melalui kegiatan-kegaitan sekolah (Julian M \& Alfred 2008: 23-38 dan Schiller \& Bryant, 2002: vi). 


\section{Bidang Bimbingan Sosial}

Layanan ini membantu peserta didik agar dapat berhubungan dengan lingkungan sekitarnya atas dasar etika pergaulan sosial yang dilandasi oleh akhlak mulia, budi pekerti luhur, dan tanggung jawab sosial (Marsudi, 2003: 85). Melalui layanan ini, peserta didik ditumbuhkan dan dikembangkan kemampuan berkomunikasi, tingkah laku sosial yang baik, membangun hubungan yang harmonis, serta pemahaman dan pengamalan disiplin terhadap peraturan bermasyarakat.

3. Bidang Bimbingan Belajar

Layanan ini membantu peserta didik mengembangkan kebiasaan belajar yang lebih baik, dalam bentuk, berkembangnya sikap dan kebiasaan belajar yang baik, mengembangkan keterampilan, serta bersikap hormat terhadap guru, serta tumbuhnya disiplin belajar dan berlatih secara mandiri (Kartadinata, 1999: 61). Menurut The ASCA National Model, bimbingan belajar diberikan dalam rangka menumbuhkan: a) keterampilan belajar, artinya peserta didik akan menerima pengetahuan, sikap, dan kebiasaan belajar baru yang akan berkontribusi dalam pembelajaran efektif, b) keberhasilan sekolah, artinya peserta didik akan menyelesaikan sekolah dengan persiapan yang lebih baik sehingga dapat memilih pendidikan lanjutan yang lebih baik bahkan sampai jenjang perguruan tinggi, dan c) belajar kesuksesan hidup, artinya peserta didik memahami keterkaitan antara belajar dengan dunia kerja (2005: 33).

4. Bidang Bimbingan Karir

Dalam karir tidak hanya cukup membekali siswa dengan keterampilan praktis, tetapi perlu terampil dalam merancang karir secara matang, bersikap baik, dan memahami diri secara utuh. Pada abad 21 ini, MI pun diarahkan mengajarkan kepada peserta didik tentang bagaimana mereka hidup, bagaiamana belajar, dan bagaimana bekerja atau berkarir. Menurut Mel Ruff (2001) bimbingan karir secara mendasar seharusnya diberikan pada seluruh peserta didik dan terintegrasi sejak tahun-tahun pertama pendidikannya. Artinya bimbingan karir yang teritegrasi dengan kurikulum pembelajaran secara berkesinambungan baik di kelas maupun di luar kelas dan dimulai sejak sekolah dasar sampai sekolah lanjutan (Worzbyt, O'Rourke, \& Dandeneau, 2003: 4 dan Ruff, dalam Gothard, 2001: 94).

Problem karir yang sering dihadapi adalah ketidaktahuan peserta didik tentang apa yang akan dan harus dilakukan. Tujuan bimbingan dan konseling karir bagi peserta didik usia sekolah dasar difokuskan untuk memberikan kesadaran dan wawasan karir kepada peserta didik atau career awareness. Artinya, layanan hanya menekankan pada peningkatan wawasan dan informasi peserta didik tentang dunia pekerjaan. Dengan harapan, peserta didik akan memahami tentang tuntutan dunia kerja, serta kaitannya dengan pendidikan sebagai proses persiapannya (Nathan \& Hill, 2006: 17 dan Kartadinata 1999: 221 dan Savickas, 2005: 48). 


\section{Model-Konsep Bimbingan Integratif-Komprehensif Di MI}

Madrasah ibtidaiyah memiliki karakteristik kurikulum dan proses pembelajaran yang khas dibandingkan dengan tingkat sekolah lain. Pembelajaran di MI banyak dilakukan oleh guru kelas. Artinya hampir semua mata pelajaran yang diajarkan, diberikan oleh seorang guru yang berfungsi baik sebagai wali kelas maupun guru kelas, serta beberapa guru mata pelajaran. Secara psikologis, kondisi ini memberikan banyak keuntungan karena pendidik memahami betul peserta didiknya. Bagaimanapun juga, layanan bimbingan dan konseling akan sangat lebih baik ketika dilaksanakan secara terpadu dan terintegrasi dengan mata pelajaran.

Paradigma keterpaduan itu tergambar dalam peribahasa sekali mengayung dayung dua tiga pulau terlampaui, sedangkan integrasi adalah memadukan materi satu dengan materi lain untuk membangun sebuah pengetahuan yang utuh dan berdampak luas. Konsep keterpaduan materi dilaksanakan dalam rangka menghasilkan dampak yang lebih luas pada setiap aspek pembelajaran misalnya aspek kepribadian, sikap, motivasi, dan keterampilan. Berarti, setiap proses pembelajaran di MI perlu dilaksanakan secara terintegrasi dengan nilai-nilai BK (bimbingan dan konseling) terutama pada aspek program, ketenagaan, prosedur atau teknik pelaksanaan, dan daya dukung lingkungan (Kartadinata, 1999: 260270).

1. Aspek Program

Program bimbingan pola perkembangan muncul berdasarkan karakteristik tugas-tugas perkembangan dan kompetensi yang ingin dicapai. Program-program bimbingan dikembangkan dari kebutuhan siswa dan masalah nyata yang ada di sekolah. Tujuannya untuk menghasilkan program yang betul-betul dibutuhkan oleh peserta didik sehingga akan memberikan manfaat lebih banyak dalam aspek pengembangan pribadi, sosial, belajar, dan cita-cita karirnya.

Isi materi bimbingan dari jenis-jenis bimbingan tersebut perlu dikembangkan secara relevan dengan konsep dan kebutuhan yang nyata yang dihadapi oleh peserta didik, meskipun penyampaiannya secara insidental. Program bimbingan dan konseling hendaknya dimasukan ke dalam programprogram KBM (kegiatan belajar mengajar) serta program sekolah lainnya. Artinya, setiap kegiatan hendaknya memasukkan nilai-nilai bimbingan dan konseling. Hal ini dikarenakan secara filosofis, setiap pengetahuan (materi pelajaran yang disampaikan) di dalamnya tersirat muatan nilai-nilai (Hartono, 2011: 77).

2. Aspek Ketenagaan

KBM tidak akan pernah berjalan tanpa guru, akan tetapi tanpa guru bimbingan konseling sekolah akan terus berjalan. Peran vital guru tersebut antara lain mendidik yang berarti menanamkan nilai-nilai, mengajar atau menransfer dan mengembangkan pengetahuan serta teknnologi, dan melatih atau mengembangkan keterampilan. Mengacu pada peran tersebut, hasil belajar dan kemajuan belajar yang akan dicapai oleh peserta didik akan sangat dipengaruhi 
dan ditentukan oleh pola hubungan antara guru dengan siswa (Gibson \& Mitchel, 2011: 107 dan Usman, 2011: 7 dan Sukmadinata, 2010: 196). Jika demikian halnya, maka seorang guru sekolah dasar perlu memiliki pemahaman yang tepat dan keterampilan yang memadai untuk melaksanakan layanan bimbingan dalam rangka mengembangkan peserta didik secara optimal. Kemampuan melakukan kegiatan bimbingan bagi guru madrasah ibtidaiyyah artinya, guru dalam proses pembelajarannya melakukan juga pemberian dorongan, bantuan, pengawasan, pengarahan, dan pemecahan masalah (Kartadinata, 1999: 269 dan Sukmadinata, 2010: 197).

3. Aspek Prosedur atau Teknik

Paradigma perkembangan menghendaki layanan bimbingan dan konseling yang berorientasi pada tugas-tugas perkembangan. Oleh sebab itu, layanan bimbingan dan konseling menghendaki adanya keterpaduan antara pendekatan dan teknik intruksional dengan transaksional. Artinya, layanan bimbingan dan konseling dilaksanakan seiring dengan proses KBM dan di luar KBM. Dalam KBM, dikembangkan aspek pribadi dan sosial serta keterampilan melalui pendekatan PAIKEM (pembelajaran aktif, inovatif, kreatif, efektif dan menyenangkan) yang arahnya mengembangkan kemandirian belajar, kepribadian, dan sosial. Di luar KBM, pelaksanaan BK dapat dilakukan melalui kegiatan karyawisata, outbond, dan kegiatan-kegaitan outdoor lainnya.

Prioritas utama tetap ditekankan pada lingkungan sekolah yang kondusif untuk pengembangan diri peserta didik melalui KBM. Pengembangan iklim pembelajaran yang kondusif dalam rangka pengembangan perilaku siswa secara efektif merupakan strategi yang dipandang sangat efektif untuk digunakan di MI (Kartadinata, 1999: 270). Dengan kata lain, layanan bimbingan dan konseling dilakukan melalui prosedur dan teknik pembelajaran, artinya selain mengajar guru juga mendesain setiap kegiatan pembelajaran yang melibatkan kegiatan layanan bimbingan dan konseling.

4. Aspek Daya Dukung Lingkungan

Proses bimbingan hanya akan berjalan dengan baik jika mendapat tempat yang layak dan diakui sehingga mampu memberi kontribusi nyata terhadap pencapaian tujuan-tujuan pendidikan. Guru bukan petugas yang dapat berkerja sendiri, akan tetapi membutuhkan bantuan dan dukungan manajerial, sosial, maupun sarana sebagai upaya peningkatan mutu pendidikan. Layanan bimbingan dan konseling membutuhkan dukungan lingkungan dalam bentuk lingkungan sosio-ekologis pendidikan yang diwarnai budaya pendidikan berbasis kompetensi dan pengembangan diri (Kartadinata, 1999: 270). 


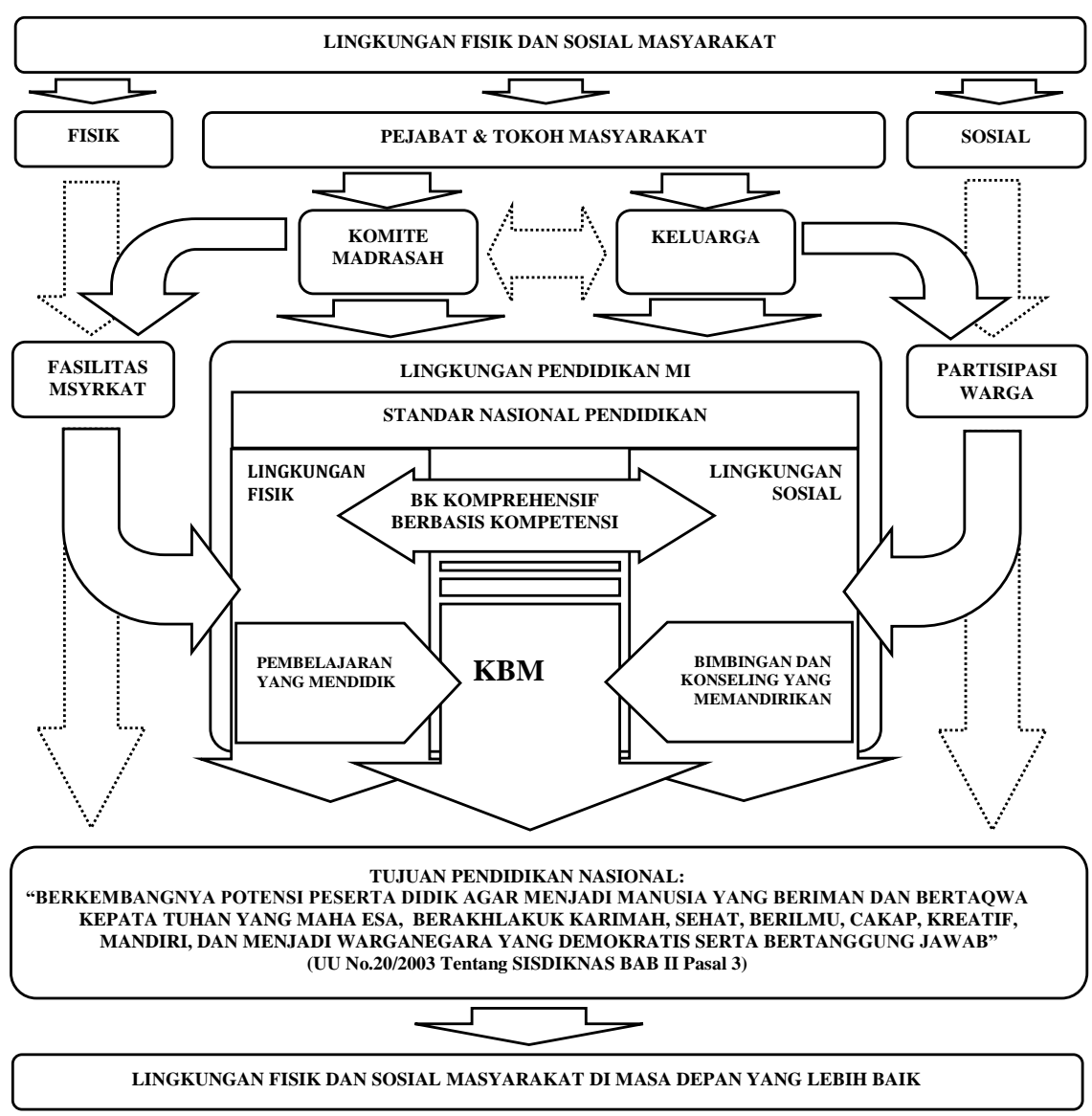

\section{Model Konsep Pola BK Integratif-Komprehensif di MI}

Pada jenjang MI, layanan bimbingan konseling dilaksanakan secara terintegrasi dan terpadu dengan proses pembelajaran. Pelaksananya didesain dalam bentuk penciptaan lingkungan yang kondusif dan proses interaksi yang akrab. Kondisi tersebut merupakan faktor yang akan mendukung peserta didik dalam mengembangkan dirinya dalam bentuk sikap dan keterampilan pribadisosial yang baik (Yusuf dan Nurihsan, 2011:11). Mengacu pada karakteristik keintegrasian, maka layanan BK di MI dilakukan secara terintegrasi dengan proses pembelajaran pada masing-masing mata pelajaran (IPA/Sains, IPS, Bahasa Indonesia, dan Kewarganegaraan). Pada Mata Pelajaran Olah Raga dan Agama secara tidak langsung seluruh materinya berisi aspek kepribadian dan sosial. Mata Pelajaran Agama di MI yang terdiri atas Akidah-Akhlak, Fikih, Qur'an-Hadis, dan Sejarah Islam sudah mengandung nilai-nilai pribadi maupun sosial yang kompleks yang merupakan penekanan pengembangan diri dalam bimbingan konseling. Pada Mata Pelajaran Matematika, secara tersirat 
mengajarkan nilai disiplin, ketelitian, dan keteraturan. Oleh sebab itu, nilai-nilai bimbingan dan konseling dalam Mata Pelajaran Matematika sangat kondisional.

Layanan Bimbingan Terintegrasi dengan Mata Pelajaran

\begin{tabular}{|c|c|c|}
\hline $\begin{array}{l}\text { Mata } \\
\text { Pelajaran }\end{array}$ & Materi Pelajaran & $\begin{array}{c}\text { Pengembangan Nilai } \\
\text { Bimbingan } \\
\text { (Pribadi-Sosial-Belajar-Karir) }\end{array}$ \\
\hline $\begin{array}{c}\text { IPA } \\
\text { Kelas I }\end{array}$ & $\begin{array}{l}\text { Tubuhku, Aku Tumbuh Sehat, } \\
\text { Lingkunganku Sehat, serta Benda Langit dan } \\
\text { Peristiwa alam. }\end{array}$ & $\begin{array}{l}\text { Menjaga kebersihan, Hidup } \\
\text { Sehat, Makanan Bergizi, Pola } \\
\text { Makan Sehat, Olahraga, } \\
\text { Menjaga Kebersihan, } \\
\text { Kerjabakti, Keagungan } \\
\text { Tuhan. }\end{array}$ \\
\hline \multirow[t]{3}{*}{$\begin{array}{c}\text { IPS } \\
\text { Kelas II } \\
\end{array}$} & $\begin{array}{l}\text { Memelihara Dokumen dan Benda } \\
\text { (Pentingnya dan Cara Memelihara). }\end{array}$ & $\begin{array}{l}\text { Tanggung jawab, tertib } \\
\text { administrasi dalam Belajar. }\end{array}$ \\
\hline & $\begin{array}{l}\text { Peranan sebagai Anggota Keluarga (Peran } \\
\text { setiap Anggota Keluarga dan Pengalaman } \\
\text { Sebagai Anggota Keluarga). }\end{array}$ & $\begin{array}{l}\text { Membantu orang tua, saling } \\
\text { menyayangi, belajar dengan } \\
\text { sungguh-sungguh. }\end{array}$ \\
\hline & $\begin{array}{l}\text { Kehidupan Bertetangga (Kerjasama di } \\
\text { Lingkungan Keluarga dan Tetangga serta } \\
\text { Manfaatnya) }\end{array}$ & $\begin{array}{l}\text { Toleransi, Saling } \\
\text { Menghomati, Tolong } \\
\text { Menolong. }\end{array}$ \\
\hline \multirow[t]{2}{*}{$\begin{array}{c}\text { PKn } \\
\text { Kelas III } \\
\end{array}$} & $\begin{array}{l}\text { Aturan di Lingkunganku (Keluarga, Sekolah, } \\
\text { dan Masyarakat) }\end{array}$ & $\begin{array}{l}\text { Taat Peraturan, Disiplin, } \\
\text { Saling Menghargai, }\end{array}$ \\
\hline & Menghargai Diri Sendiri dan Orang lain & Kepedulian dan Empati \\
\hline \multirow[t]{2}{*}{$\begin{array}{c}\text { IPA } \\
\text { Kelas IV }\end{array}$} & $\begin{array}{l}\text { Struktur Rangka Manusia dan Perawatannya } \\
\text { Sehari-hari }\end{array}$ & $\begin{array}{l}\text { Menjaga Kesehatan Diri, } \\
\text { Merawat Diri Sendiri, } \\
\text { Kebiasaan belajar yang baik } \\
\text { dan disiplin. }\end{array}$ \\
\hline & Panca Indra dan Perawatannya & $\begin{array}{l}\text { Menjaga Kesehatan Diri, pola } \\
\text { belajar yang sehat. }\end{array}$ \\
\hline $\begin{array}{c}\text { IPS } \\
\text { Kelas IV }\end{array}$ & $\begin{array}{l}\text { Menghargai Keragaman Suku Bangsa Sosial } \\
\text { dan Budaya (Keragaman Suku Bangsa dan } \\
\text { Budaya Setempat, Bentuk Keragaman di } \\
\text { Indonesia, Pentingnya Menjaga Persatuan } \\
\text { dalam Keberagaman, Menghargai } \\
\text { Keberagaman dalam Hidup Bermasyarakat) }\end{array}$ & $\begin{array}{l}\text { Adil, Saling Menghargai, } \\
\text { Saling Menghormati, } \\
\text { Toleransi, Rukun, }\end{array}$ \\
\hline $\begin{array}{l}\text { Bahasa } \\
\text { Indonesia } \\
\text { Kelas IV }\end{array}$ & $\begin{array}{l}\text { Sopan Santun Berkomunikasi } \\
\text { (Menyampaikan Pesan, Menyampaikan } \\
\text { Kembali isi Pengumuman) }\end{array}$ & Sopan, Ramah, \\
\hline \multirow[t]{2}{*}{$\begin{array}{c}\text { IPS } \\
\text { Kelas V } \\
\end{array}$} & $\begin{array}{l}\text { Keragaman Suku Bangsa dan Budaya } \\
\text { (Keragaman Suku Bangsa dan Budaya) }\end{array}$ & $\begin{array}{l}\text { Saling Menghormati, Saling } \\
\text { Menghargai, Toleransi, }\end{array}$ \\
\hline & $\begin{array}{l}\text { Perjuangan Mempertahankan Kemerdekaan } \\
\text { (Usaha Diplomasi, Pengakuan Kedaulatan, } \\
\text { Menghargai Jasa Tokoh Perjuangan dan } \\
\text { Kemerdekaan) }\end{array}$ & $\begin{array}{l}\text { Semangat, Rela Berkorban, } \\
\text { Cinta Tanah Air }\end{array}$ \\
\hline $\begin{array}{l}\text { Bahasa } \\
\text { Indonesia } \\
\text { Kelas V } \\
\end{array}$ & $\begin{array}{l}\text { Bersikap Jujur dalam Kehidupan (Mengenal } \\
\text { Unsur Cerita Rakyat, Berwawancara dengan } \\
\text { Narasumber, Membaca Teks Percakapan) }\end{array}$ & Kejujuran dan integritas, \\
\hline
\end{tabular}




\begin{tabular}{|c|l|l|}
\hline $\begin{array}{c}\text { Mata } \\
\text { Pelajaran }\end{array}$ & \multicolumn{1}{|c|}{ Materi Pelajaran } & \multicolumn{1}{|c|}{$\begin{array}{c}\text { Pengembangan Nilai } \\
\text { Bimbingan } \\
\text { (Pribadi-Sosial-Belajar-Karir) }\end{array}$} \\
\hline $\begin{array}{c}\text { PKn } \\
\text { Kelas V }\end{array}$ & $\begin{array}{l}\text { Peraturan dan Undang-Undang (Peraturan } \\
\text { Perundang-Undangan Pusat dan Daerah, } \\
\text { Contoh Peraturan Perundangan Pusat dan } \\
\text { Daerah Serta Menegakkannya) }\end{array}$ & $\begin{array}{l}\text { Loyalitas, Taat Peraturan, } \\
\text { Sadar Hukum, }\end{array}$ \\
\hline $\begin{array}{l}\text { Menghargai dan Menaati Keputusan } \\
\text { Bersama (Bentuk-Bentuk Keputusan }\end{array}$ & $\begin{array}{l}\text { Bersama, Melaksanakan Keputusan } \\
\text { Bersama, Praktik Mengambil Kputusan } \\
\text { Bersama) }\end{array}$ & $\begin{array}{l}\text { Kerjasama, komitmen dan } \\
\text { keteguhan hati, Musyawarah, }\end{array}$ \\
\hline $\begin{array}{c}\text { IPS } \\
\text { Kelas VI }\end{array}$ & $\begin{array}{l}\text { Cara Menghadapi Bencana Alam (Gempa } \\
\text { Bumi, Tsunami, Gunung Meletus, Angin } \\
\text { Topan, Banjir, Kebakaran Hutan) }\end{array}$ & $\begin{array}{l}\text { Kepedulian dan Empati, Suka } \\
\text { Menolong, }\end{array}$ \\
\hline $\begin{array}{l}\text { Bahasa } \\
\text { Indonesia } \\
\text { Kelas VI }\end{array}$ & $\begin{array}{l}\text { Dunia Binatang (Belajar Menyampaikan } \\
\text { Informasi, Mendeskripsikan Laporan } \\
\text { Kunjungan) }\end{array}$ & $\begin{array}{l}\text { Rasa Percaya Diri, Rendah } \\
\text { Hati, }\end{array}$ \\
\hline $\begin{array}{c}\text { PKn } \\
\text { Kelas VI }\end{array}$ & $\begin{array}{l}\text { Nilai Perjuangan dalam Pancasila (Pancasila } \\
\text { sbg Dasar Negara, Proses Perumusan } \\
\text { Pancasila, Nilai-nilai Juang dan } \\
\text { Kebersamaan, Meneladani Nilai Juang dan } \\
\text { Kebersamaan pada Tokoh, Mengamalkan } \\
\text { Pancasila) }\end{array}$ & $\begin{array}{l}\text { Kerjasama, Berani, Ulet, } \\
\text { Bangguh, Tegar, Rela } \\
\text { Kerkorban, Semangat } \\
\text { Kebersamaan, Patriotik, }\end{array}$ \\
\hline
\end{tabular}

Nilai-nilai bimbingan dan konseling tersebut selanjutnya dijabarkan dalam setiap materi pelajaran yang dikembangkan dalam bentuk RPP materi pelajaran. Model RPP yang digunakan adalah RPP Model Tematik yang telah dimodifikasi, yaitu memasukkan nilai-nilai bimbingan dan konseling yang disampaikan serta keterlibatan pihak lain sebagai wujud dukungan sistem.

\section{RENCANA PELAKSANAAN PEMBELAJARAN}

Satuan Pendidikan

Tema Pembelajaran

Kelas / Semester

Pelaksanaan

Alokasi Waktu
A. Standar Kompetensi
B. Kompetensi Dasar
C. Indikator Ketercapaian
D. Pengembangan Nilai Bimbingan dan Konseling
E. Pihak yang Dilibatkan
F. Materi pokok
G. Metode, Media, dan Sumber Belajar
H. Manajemen Pembelajaran

\section{Pembukaan}


2. Kegiatan inti (Pembentukan karakter dan kompetensi)

a. Bahasa Indonesia
1) Eksplorasi
2) Elaborasi
3) Konfirmasi
4) Kesimpulan

b. IPA
1) Eksplorasi
2) Elaborasi
3) Konfirmasi
4) Kesimpulan

c. IPS
1) Eksplorasi
2) Elaborasi
3) Konfirmasi
4) Kesimpulan

3. Penutup dan Penilaian

I. Evaluasi Tes tertulis

J. Penilaian Kinerja / Performasi

1. IPS

2. IPA

3. Bahasa Indonesia
K. Produk
L. Penugasan /Proyek
M. Portofolio
N. Refleksi

Mengetahui,

Kepala MI
Guru Kelas II

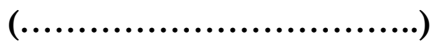

\section{SIMPULAN}

Upaya meningkatkan mutu madrasah ditandai dengan kesadaran pemerintah mendorong pemberlakuan Model Kurikulum Tematik di MI. Model Tematik menghendaki adanya keutuhan pemahaman dan penguasaan materi secara komprehensif pada peserta didik. Konsep integratif-komprehensif dibagi ke dalam tiga komponen utama pendidikan yaitu; 1) kepemimpinan/manajerial, 2) pembelajaran, dan 3) pengembangan diri. Layanan Bimbingan dan Konseling di MI yang mencerdasakan dan memandirikan peserta didik melibatkan dukungan manajemen madrasah dan orang tua murid. Untuk itu, diperlukan model konsep bimbingan dan konseling integrative-komprehensif yang dapat diaplikasikan secara prosedural dan operasional. Isu integrasi keilmuan yang sudah lama diperbincangkan dan kini mulai diterapkan pada sains dan agama memuluskan langkah penyusunan model-konsep manajemen bimbingan 
konseling integrative-komprehensif di MI. Model tersebut dirancang menekankan pada keterpaduan aspek program, ketenagaan, prosedur, serta dukungan sistem layanan. Model ini pun menghendaki KBM sebagai nilai utama pendidikan di MI dapat mengembangkan aspek kepribadian siswa seperti kepribadian, sosial, akademik/belajar, prospek karir di masa depan, bahkan kesusilaan. Jadi, format RPP yang mengintegrasikan nilai-nilai bimbingan dan konseling di MI bukan sebatas gagasan untuk operasionalisai manajemen BK di MI, melainkan juga adanya sejumlah prosedur yang menjadikan peserta didik sadar akan pentingnya bersyukur kepada Allah swt. Atas dasar itu, ilmu pengetahuan yang dimiliki, kesungguhan dalam mencari ilmu dan mengamalkannya, kemauan untuk berprestasi dan unggul dibidangnya, serta terinternalisasinya sikap sosial yang lebih baik atas dasar pengetahuan dan pemahaman dirinya sebagai makhluk ciptaan Allah, dapat menciptakan lulusan MI yang memiliki kompetensi unggul dan siap bersaing.

\section{DAFTAR PUSTAKA}

Luddin, Bakar, Abu, M. 2010, Dasar-Dasar Konseling: Tinjauan Teori dan Praktik, Bandung: Citapustaka Media Perintis.

Suwarna, 2007, Strategi Integrasi Pendidikan Budi Pekerti dalam Pembelajaran Berbasis Kompetensi, Jurnal Ilmiah Pendidikan: Cakrawala Pendidikan, Februari 2007, Th. XXVI, No. 1.

Nawawi, Ahmad. 2011, Pentingnya Pendidikan Nilai Moral bagi Generasi Penerus, Jurnal Kependidikan: Insania, Vo. 16 No. 2, Mei-Agustus 2011.

Tafsir, Ahmad. 2010, Filsafat Pendidikan Islam: Integrasi Jasmani, Rohani dan Kalbu Memanusiakan Manusia, Bandung: Remaja Rosdakarya.

ASCA. 2005. The ASCA National Model: A Framwork for School Counseling Programs, Second Edition, Alexandria: ASCA.

Azra, Azyumardi. 2006. Paradigma Baru Pendidikan Nasional: Rekonstruksi dan Demokratisasi, Jakarta: Kompas.

Sukardi, Ketut, Dewa \& Kusmawati, Nila, Desak. 2008, Proses Bimbingan dan Konseling di Sekolah, Jakarta: Rineka Cipta.

Hartono, 2011, Pendidikan Itegratif, Purwokerto: STAIN Press.

M, Julian, James \& Alfred, Johan. 2008, Belajar Kepribadian: The Accelerated Learning for Personality (Terjemahan: Tom Wahyu), Yogyakarta: Pustaka Baca.

O’Rourke, Kathleen, Worzbyt, John C. \& Dandeneau, Claire, 2003, Elementary School Counseling: A Commitment to Caring and Community Building-2nd Edition, New York: Taylor \& Francis Books, Inc.

Geldard, Kathryn \& Geldard, David, 2001. Counseling Children: A Practical Introduction, London: SAGE Publication.

Savickas, Mark L. 2005. The Theory and Practice of Career Construction dalam Career Development and Counseling: Putting Theory and Reseach to Work (Ed. W. Lent), New Jersey: John Wiley \& Sons, Inc. 
Ruff, Mel, 2001, Careers Education dalam Careers Education in Context (Eds: Bill Gothard, dkk.). London: SAGE Publications.

Usman, Uzer, Moh. 2011. Menjadi Guru Profesional, Bandung: Remaja Rosdakarya.

Sukmadinata, Syaodih, Nana 2010, Pengembangan Kurikulum: Teori \& Praktik, Bandung: Remaja Rosdakarya.

Schiller, Pam \& Bryant, Tamera, 2002. 16 Nilai Moral Bagi Anak, Jakarta: Elek Media Komputindo.

Prayitno \& Amti, Erman. 2009, Dasar-Dasar Bimbingan dan Konseling, Jakarta: Rineka Cipta.

Gibson, Robert L. \& Mitchel, Marianne H. 2011, Bimbingan dan Konseling, Yogyakarta: Pustaka Pelajar.

Nathan, Robert \& Hill, Linda, 2006, Career Counseling. Second Edition. California: SAGE Publication.

Marsudi, Saring dkk., 2003, Layanan Bimbingan Konseling di Sekolah, Surakarta: Muhammadiyah University Press.

Sjarkawi, 2011, Pembentukan Kepribadian Anak: Moral, Intelektual, Emosional dan Sosial sebagai Wujud Integritas membangun Jati Diri, Jakarta: Bumi Aksara.

Slameto, 2010, Belajar dan Faktor-Faktor yang Mempengarubinya, Jakarta: Rineka Cipta.

Kartadinata, Sunaryo, dkk., 1999, Bimbingan di Sekolah Dasar, Jakarta: Depdikbud.

Yusuf, Syamsu \& Nurihsan, Juntika, 2011, Landasan Bimbingan \& Konseling, Bandung: Remaja Rosdakarya \& PPs UPI.

Tidjan, dkk., 2000, Bimbingan dan Konseling Sekolah Menengah, Yogyakarta: UNY Press. 